\title{
AI VISION \#1 - GOODBYE ASYMMETRIC INFORMATION FOR PATIENTS?!
}

Szerző:

Dr. Zorkóczy Miklós Zorkóczy Ügyvédi Iroda

Szerző e-mail címe: miklos@drzorkoczy.hu
Lektorok:

\author{
Mező Ferenc (PhD) \\ Eszterházy Károly Egyetem \\ Simó Ferenc Zoltán (Dr. Jur.) \\ Debreceni Egyetem
}

...és további két anonim lektor

\begin{abstract}
Absztrakt
A telemedicina szárnyán, egy vállalkozó orvos szemszögéből részt vehetünk egy Üzleti Angyal befektésben és exitben, megnézhetjük az orvosi társadalom szempontjait, majd a piaci kudarcot egy újabb VC befeketés menti meg, létrejön a kormányzati szabályozás, és intézményesül az innováció. A tanulmány jogi, közgazdasági, egészségügyi, adatvédelmi témákat érint, azokat összefüggéseiben tárgyalja, felvetítve egy elképzelt jövőbeli mesterséges intelligencia által támogatott technológiai és egészségügyi - társadalmi jövőképet.
\end{abstract}

Kulcsszavak: Egészségügyi jog, Mesterséges Intelligencia, Telemedicina, adatvédelem

Diszciplinák: orvostudomány, jogtudomány, közgazdaságtudomány

\section{Abstract \\ AI VÍZIÓ \#1 \\ - VISZL ÁT BETEGEKNEK SZÓLÓ ASZIMMETRIKUS INFORMACIÓK?!}

Having a ride in a future $\mathrm{AI}$ investment project, you can see a telemedicine start up from a physician point of view, you will see a Business Angel investment and exit, also a market failure cured by a VC investment, a government ruling and finally the vision of innovation. The article is about legal, economic, medical and data privacy issues and their close consequences in a future AI innovation.

Keywords: medical law, AI, telemedicine, Healthcare, data privacy

Disciplines: medicine, law and economy

Zorkóczy Miklós (2021): AI Vision \#1 - Goodbye asymmetric information for Patients?! Mesterséges intelligencia - interdiszciplináris folyóirat, III. évf. 2021/1. szám. 9-17. doi: 10.35406/MI.2021.1.9 
Patients, Physicians, Social Funds, VCs and Regulatory were all happy, though they had not had any trust in using AI at the beginning. Having a ride in a future AI investment project, you can see a telemedicine start up from a physician point of view, you will see a Business Angel investment and exit, also a market failure cured by a VC investment, a government ruling and finally the vision of innovation. The article is about legal, economic, medical and data privacy issues and their close consequences in a future $\mathrm{AI}$ innovation.

\section{Asymmetric information in Healthcare}

Once upon a time, a Medical Resident recognized that the leaflets at the reception desks in his/her hospital were not up to date. The receptionists were not always well informed about the changes, and sometimes the quality of information the Patient received were depending on the personal current ability to answer. While the Resident was responsible to give proper information to Patients of his/her medical care to have the consent for the treatment, Residents realized that so much information was about non - medical questions though he/she was not experienced to answer them or was not up to dated. Why not to digitalize it and automatize the whole info process? - he asked.

It was obvious that the informed consent of any medical treatment could not rely on "smart computers". Patients' point of view he/she would not understand fully his/her diagnosis, the available care and therapy, the costs and efficiency, the costs and efficacy. So, he/she would rely on his doctor's (as an agent) opinion and based on this suggestion he/she (as Mandator) would give the consent on the treatment. If an Agent made the decision, and he/she was part of the service, this would be the situation when supplier induced demand. Monopoly situation which could be balanced by medical guidelines and protocols or make patients financially interested to get as much as information available by a mechanism of co-insurance, co-payment, deductibles (Gulácsi, 2005). The lack of proper information to give informed consent let lawyers easy to win in front of a court to claim for compensation on behalf of patients instead of demand compensation for medical malpractice. This was the reason why hospitals would not approve to give information indirectly via outside telemedicine solutions, since the hospital would be responsible in such court actions. To avoid such cases, hospitals had their own policies and protocols to inform the Patient as their local specialties. So, the info asymmetry still stood against Patient which could be balanced by legal or financial mechanisms.

\section{Startup}

The young Medical Resident met IT fellows and lawyers to find out how to save time for medical professionals and give 
Patients more info. The IT solution collected information from hospitals and could satisfy Patients (like consumers) to manage an always available, a researchable, a printable, and an up-to-date webpage. None of the hospitals wanted to be partner since the legal difficulties of giving proper information was legal risk for them, but a Business Angel found the market niche, lots of computable data and lots of customers always meant big profit. The investment process was not easy, black box affect, regulatory issues, the negative and defensive approach of hospitals made the business plan uncertainty, and it was extremely hard to draft a joint venture agreement. The Busines Angel was engaged to make investments which had social impact, in this way he/she could agree in such a risky term sheet.

\section{Market proof}

As a result of the investment, the "medical yellow pages" (hereinafter Teledoc) was launched and set up a common platform for the Hospitals and Patients. Teledoc was free for everyone, including any service providers. First, they collected useful but non-medical information, Teledoc took over the management of useful information and it was a public interest. Teledoc became a trusted source of information, it was popular among Patients. General medical information like how to get prepared for blood collection, when and what to eat or drink before and after it. Teledoc system developed itself like deep learning mechanism, the Patient asked, and the Physicians answered. In this way Teledoc system developed a huge database case by case, which was clean, systematic, and professional. Also, each hospital features could also be handled in accordance with local protocols, the Patient could choose how to get prepared for treatment according to his/her place of residence. For example, what is expected in the local hospital in case of maternity, what "hospital package" should be prepared, what was allowed to take to hospitals and what was not, what baby clothes and things could be taken, when and who could visit the maternity department. The development of telemedicine was the next step to become popular, and other policlinic and primary care providers wanted to join. They used a booking system, which was available free of charge to all participants. It was only one step to contact the doctor directly via the Teledoc's infrastructure, either over the web or even over the phone, to avoid tumult and waiting in the corridors. The revenue corners of Teledoc also developed as planned, and pharmaceutical companies, private providers, lifestyle, and wellness companies immediately joined Teledoc, which now has thousands of registered users and dozens of institutions. With profits from sponsorship fees and other advertising, the 4-person management was able to buy out the initial investor, who were able to exit his/her investments at a high return. 


\section{Market failure}

Telemedicine companies such as Teledoc became popular, and the control authorities received more complaints about such companies, and also the majority of the health society was not happy either. While some healthcare professionals noticed that they were able to spend more time dealing with the Patients, they already arrived well informed for the examinations. Yet most doctors felt tired and frustrated by the way Patients handled the information they had received via Teledoc and other Telemedicine Companies, and doctors' response to questions generated three other questions. Some Patients even asked their doctors to have more available tests or other treatments. It remained the responsibility of service provider's to obtain the Patient's consent for the treatment, and unregulated telemedicine providers had confused the previous established communication habits of doctors, and thus the principle of gradual information was not fulfilled. At the same time, the expansion of Teledoc slowed down, fixed costs had increased, sponsors had not only supported Teledoc, so the source of revenue were distributed among other Telemedicine companies.

\section{Government intervention}

Facing of many complaints, the control authorities carried out targeted and subject-matter investigations. Based on the authority findings, the government commenced to create additional strict professional and substantial conditions for Teledoc and similar companies. For example, full-time employment of an adequate staff, ongoing reporting and internal regulatory obligations, high information security requirements, standards for consumer protection and service levels. The fulfilment of increased personnel and tangible requirements meant increased expenditures in addition to stagnant revenues, and profitability declined rapidly.

\section{Co-investment}

After the successful Business Angel investment and exit, the management of Teledoc decided to invite a co-investor to make the company profitable again. The investor, who came as a regional venture capital fund, started development with professional portfolio managers, extensive business relationships and a regional approach. After extensive market research and analysis, it revealed that the future lies in the data economy. In Healthcare this meant, that along with "bedside" as well as "webside" should have been a channel for health information and communication. Information of Patients were managed in a health administration system and database, which was introduced in the meantime by the government, which recorded the Patient's medical history and treatment in the System. In addition, individual measuring devices could help a lotespecially in emergency situations. The 
hypochondriac measured his/her heart rate and blood pressure in every 4 hours a day and noted the measurements in a school booklet so that he/she could show his/her Doctor what his/her illness was. Why do you need hypochondria to detect this these days? You have got the smartwatch, the fitness watch, you just must be able to get the data out of it. Not to mention what a goldmine this could be for a pharmaceutical company in clinical research. Recognizing the latter, a lot of smart devices became available for people who registered for free. Which was not free of charge, since the user paid for it with his/her data, but Patients had a common interest in health care for the research.

\section{Legal \& Social obstacles}

Investments were converted to data assets, huge regional and global databases were created, the computing capacity to manage them were developed, and they needed to be managed. The legal obstacle to manage data was primarily a rethinking of data privacy rules. From a data protection point of view, specific health rules have been developed which, on grounds of health interest, as a stand-alone legal basis, had allowed the controller to use the health data, which were special (sensitive) data, in large numbers, by means of machine processing, anonymously for research purposes, or to be transferred, recorded, evaluated, and extracted, even online, in a non- anonymous manner based on the same legal basis.

The other obstacle against innovative data management tools was because Doctors were obviously unwilling to use data, they did not measure at first. It remained Doctors' responsibility to make a diagnosis, and according to their studies, they had to carry out the tests based on measurements under credible and laboratory conditions. Therefore, the Government required in its mandatory training system to introduce new results related to the data economy. Doctors, based on their own experience, realized that these unauthenticated devices could raise suspicions, even if they had not provided certainty. Thus, while maintaining liability rules, modern tools and methods have been integrated into healthcare, a secure and responsible data industry was established in healthcare, which picked up, managed, processed, operated, protected, developed the hardware and software environment, cleaned, analyzed, and researched data, which required enormous computing capacity, automation, and the development of new kinds of cognition and coding innovation. The deep learning machine, a special type of artificial intelligence deployed in several fields, was the right tool for this.

\section{Speed up of implementing innovative technologies}

Accelerated events happened during an unfortunate pandemic. The Doctor's appointment in primary care required the 
use of modern means of communication. Due to the possible and fragmentation of individual clinic and hospital booking systems, it was no longer able to avoid mass waiting rooms. Therefore, there was a need at government level for the use of modern tools and institutional telemedicine. It was not possible to build this immediately, so governments had two options: either involve the Teledoc and Telemedicine services, web doctor applications, management systems available on the market, call center applications. Second option was that government bought such companies and, by regulation, establishes a single Patient journey management system.

\section{AI changed}

\section{the asymmetric information flow}

As the pandemic had passed, the need of immediate digitization made the medical society realized that innovative tools were not against them, and successfully supported their operation. Teledoc became a healthcare customer contact center, using the most advanced artificial intelligence opportunities, and was on the market as a regional provider. The revenues included social security funding, such as care management selected through public procurement and outsourced in this way, whose policies, professional protocols and measurement, key indicators were developed jointly by the service providers with the Social Insurance Funds. Care management via the Patient pathway calculated on the Patient's initiative and input a personalized assessment of when testing, intervention and treatment are expected, taking account the waiting lists available from the hospital databases. The Patient could then decide whether to follow the recommended path or follow the path of his doctor, who may also initiate the optimal determination of the Patient's path in the system.

The efficiency and effectivity of the medical service was also analyzed by using artificial intelligence system on the social security side. In this way the Health Administration, Social Security and Supervising Authority were able to control spending and efficiency, so that the service providers could gain bonus revenues rather than performance limitations in case over performance of key indicators.

Decisions of financing are still not made by Patients, often not by doctors, but by providers and the Funds. However, the monopoly of supply and information asymmetry can be counterbalanced using such innovations by processing accurate and up-to-date information obtained during Patient route management and follow-up. The information thus processed and the Patient's personal feedback on the changed or restored quality of lifestyle (health stock - Gulacsi, 2005) the treatment itself, the quality of the personal and material conditions, the style in which the patient was informed, the Doctor- Patient communication, all allowed for further improvements in Healthcare. 


\section{AI Future - Utopia?}

Innovations of smart computers and data technology improvements changed the law, key players of the Health Market could have been the engine of development, the question was just the timing.

Smart computers \& Law: Computing capacities were available to exploit the clean and uniform databases. After legislation established the special legal basis of controlling and managing medical data, that could be researched anonymously, the use of artificial intelligence (AI) was expanding. The liability for causing damages was still on the Service Provider's behalf, who was responsible for approving smart computer's operation. The company which produced the hardware and software background of smart computers would be the final to pay for the compensations in case of damages. The smart computing companies had to had special insurance for this risk to cover and had to paid contribution to a special Fund. The special Fund Managers would be market supervisors as well, and they would create standards and ethical codes and would watch the market by using independent supervisors.

Social Funds and Patients: Using of innovative Healthtech solutions increased the costs of Funds first. At the same time, Patients were much keen on buying innovative services even if they had to pay extra fee for it, the Patient's Trust in AI sprang up, so the medical innovations and investments improved year on year, the rapid increase and market utilization of the technology gained further innovations, and access for Patients to medical services improved. As a result of increased access to medical services, the Funds had more Patients, and they gained higher income.

Medical Staff: The fear of health workers of losing their jobs by using smart computers and machines did not prove the truth. New jobs were created for the operation, programming, development and testing of smart computers, or machines managed by AI solutions. To teach a computer to be smart needed huge number of qualified professionals and new job functions, new professions had to be educated in Schools as well.

Venture Capital investors ( $\left.V C s^{\prime}\right)$ : Clinical trials to find subjects never had been easy, but after startups tested AI on huge amount of anonymous data to learn from, the medical services and products were easier and faster, and even cheaper got to regulatory admissions. VC investments could afford to take high risks to be guinea pigs in the use of AI in HealthTech Industry and had successful exits. After the market proof of AI services in Health Industry, the risk of investing HealthTech was reduced, so everyone wanted to invest into the "Goldmine".

\section{Predictions and possible future products $\&$ services}

Radiology: In the case of mammogram screenings, two independent medical 
opinions were required at the time of diagnosis. In this resource intensive area, with the introduction of the AI application, the problem of missing medical human resources was almost solved. After many years of clinical tests, one of the two mandatory medical opinions would be replaced by machine processing and pre-screening, the AIbased application achieved and surpassed the processing capacity of a human professional through thousands of analyses. Although it was still a doctor who made the final diagnosis, in the field of imaging diagnostics, the possibility of spreading AI would have been opened (Net1).

Screening test: In shopping centers, the former photo shop booths for ID card photos were replaced by AI rapid screening stations. The patient placed his/her palm in the booth on a diagnostic surface through which he/she examined his/her pulse, heart rate, skin, hair, and nail condition, performed an automatic voice sample analysis, asked a few questions about the patient's complaint or condition, answered questions, and gave quick suggestions as to which general practitioner or specialist to visit with his/her complaint. In return for the charges, the Patient received medical data and suggestions by e-mail or phone, giving him/her the available office contact details of his/her doctor (Gáti, 2020).

Surgery: From remote locations, via a $5 \mathrm{G}$ data transmission channel, minor surgical procedures can be performed using ro- botic arms, which AI continuously analyses and assists, for example by providing hand tremor insurance to the doctor operating through the robotic arms. (see: a 'Banana Operation' in Net2).

Pharma: Companies and authorities, especially Patients, no longer had to fear falsification of medicines after using AI and blockchain technology. Blockchain ensures the control of safe drug pathway data, and AI evaluated of large amounts of data. Pharma companies and also Authorities, Social Funds could track unnecessary prescriptions and purchases, but also they could ensure that counterfeit medicines do not reach the market.

Clinical research: In many cases, AI accelerates research phases or even skips individual steps in the field of individual diseases, the physiological effect of the molecular compositions in the test tube is tested by computer simulation (Callaway, 2020).

Inpatient care: Inpatient care had also undergone a major change, the charts and Patient documentation were no longer kept manually. The nurse recorded the Patient's condition in a voice system, so that it was processed immediately. The following shift staff saw every single medical data that had been recorded. General disinfection of rooms, collection of laundry and garbage was carried out by self-driven robots. AI based system calculated individually the food proportions, based on medical and dietetic recommendations, depending on personal body weight, blood type and daily 
movement, and took care of procurement orders and logistics. Meals were also distributed by self-propelled robots and also logged the leftovers when collecting the dishes and generated a report to the Patient's file (Ráski, 2020, Meskó and Radó, 2020).

Dentistry: At the dentist, a 3D technology device was used to map the Patient's mouth, teeth and previous panoramic Xrays, which allowed the dental technician to customize the new tooth or dentures using an artificial intelligence application. This design was presented to the Patient, who could choose additional shapes, patterns, color codes based on dental plans (CAM) made from his/her own mouth. The approved tooth test (patient's consent) would be sent online, which would also be printed by a third provider's artificial intelligence 3D printer (CAD) and delivered to the dentist. If oral surgery was required or an implant was implanted in the mouth, the oral surgeon was assisted by artificial intelligence on a 3D projector to show how deep he could drill, where to drill exactly when the patient moved in, and where not to drill, where nerves ran (Net3).

\section{References}

Callaway, E. (2020): 'It will change everything': DeepMind's AI makes gigantic leap in solving protein structures. Downloaded: 2021.03.10. Web:

www.nature.com/articles/d41586020-03348-4
Fehér, K., Kökényesi Bartos, A. \& Bártfai, B. (2020): Mesterséges intelligencia avagy Pandora digitális szelencéje. Budapest (HU): BBS-INFO.

Gáti, J. (2020): Nem képtelenség? /Not nonsense?/ HVG, 2020.10.08, p. 50.

Gulácsi, L. (2005): Egészség-gazdaságtan /Health Economics/. Budapest (HU): Medicina

Meskó, B. \& Radó, N. (2019): The Medical Futurist: The technological future of medical specialties. Budapest (HU): Webicina Tanácsadó és Szolgáltató Kft.

Net1. Downloaded: 10.06.2021, Web: www.kheironmed.com

Net2: Tele-surgery performed by a London-based surgeon on a banana fruit in California, using the 5 G commu. Downloaded: 12.06.2021. Web: https://www.youtube.com/watch?v= 5jn8fjLXTiI

Net3: Fájhat a fogunk a robotra, amely segít, ha fáj a fogunk. HVG, 2020.11.02. . Downloaded: 20.11.2020. Web: https://hvg.hu/360/202044_robotde ntista_fajhat_afogunk_ra

Ráski, P. (2020): A szolgáltató robotok gyorsan terjednek /Service robots are spreading rapidly/. Világgazdaság /World Economy/, 52. évf., 206. szám, 2020.10.26., p. 2 Web: https://www.vg.hu/kozelet/2020/10 /gyorsan-terjednek-a-szolgaltatorobotok-2 